\title{
Strategic Conception about Impelling the Financial Integration between Taiwan and Mainland
}

\author{
Qin Chen \\ The Department of Finance \\ Fuzhou University of International Studies and Trade \\ Fuzhou, China \\ chenqinzhuren@sina.cn
}

\author{
Yan-Yan Yao \\ The Department of Finance \\ Fuzhou University of International Studies and Trade \\ Fuzhou, China \\ 369491301@qq.com
}

\begin{abstract}
This paper is mainly about strategies that impel financial integration between Taiwan and mainland. Firstly, it shows there are restrictions preventing the financial integration between both areas, which are caused by currency clearing mechanism, directly currency exchanging and financing of local companies in Taiwan. After a series of theoretical analysis, the paper will give some reasonable advices, as solution for those restrictions, in terms of policy making. Those solutions are specific to currency clearing mechanism, directly currency exchanging and financing of local companies in Taiwan, which is the creative points of this paper.
\end{abstract}

Keywords-financial integration; currency clearing; financial regulatory; tendency

\section{INTRODUCTION}

Nowadays, accompanied with the development about economic integration in global and regional terms, there are increasingly more trades between Taiwan and mainland, which stimulates and permeates the financial cooperation between both areas [1]. It is necessary for both areas to have a solid financial integration. This paper illustrates there are restrictions preventing the financial integration between both areas, which are caused by currency clearing mechanism, directly currency exchanging and financing of local companies in Taiwan. Furthermore, in order to break those barriers, the paper will give a series of reasonable advices in terms of policy making.

\section{INEVITABLE TENDENCY OF FINANCIAL INTEGRATION AND COOPERATION BETWEEN MAINLAND AND TAIWAN}

\section{A. The booming of economic and trade developments}

Taiwan always has a significant trade surplus with mainland. The trade surplus in 1993 is 11.47 billion dollars. And it also be demonstrated that the trade surplus is 40.36 billion dollars in 2003. Moreover, the figure in 2013 is 11.6 billion dollars. The up-to-date data from commerce department shows that the value of trade between two areas is 188.56 billion dollars, which decreases by 4.9 percent year on year. This data shows that the amount of export from mainland to Taiwan is 44.9 billion dollars, which declines by 3 percent year on year. On the other hand, the mainland's import from Taiwan is 143.65 billion dollars, which reduces by 5.5 percent year on year. Taiwan is the seventh largest trade partner for mainland and the sixth largest import sourcing area of mainland [2]. Mainland is the largest trade partner to Taiwan and source of trade surplus for Taiwan. As the increasing of the scale in economic and trade communication between two areas, the financial collaborating between them becomes more and more intensive. This builds solid fundamental for the financial integration and cooperation between two areas [3].

\section{B. Facing of the challenge caused by globalization and regionalization}

Accompanied by the development of financial liberalization and globalization, the combination of financial market in different countries is increasingly tighter, which intensively stimulates them to develop towards financial integration [4]. In the intensive development of economy globalization and regionalization, there are three main problems which need to be solved. The first one is about to concordance comparative advantages in financial terms, which can help both areas to maximize their profit. Next, coordinating competition and conflict between two areas are also necessary. It can help the two areas to deal with the uncertainty and risk of international market [5]. The last problem is about preventing marginalization to increase the international competitiveness. One possible and effective solution for those problems is that the mainland and Taiwan should realize the financial integration as soon as possible, which can help them to adapt the change in world economic environment effectively. If the integration between Taiwan and mainland can be successfully achieved, they can form a customs union. This can not only increase their bargaining power in the international market, but also let them participate international economic activity as one economic community. Furthermore, it will increase their international competitiveness in large extend ${ }^{[6]}$.

\section{THE MAIN BARRIERS FOR FINANCIAL INTEGRATION}

\section{A. Remittance barriers between Taiwan and mainland}

Firstly, the remittance in two areas is not fully permitted. There are many barriers for remittance. For example, the amount of remittance for non-commodity and non-labor reason is limited. Moreover, the direct remittance for purpose of direct investment, securities investment or other aim without permission is not permitted. There are only half of local banks in Taiwan, which have got permission for direct remittance. This means that many local banks in Taiwan are 
not able to provide the direct remittance services from Taiwan to mainland.

Secondly, the direct remittance in two areas is not completed. The direct remittance between two areas relies on the currency which belongs to the third party. With the participation of the third currency, the settlement in mainland and Taiwan can only be completed. The reason is that there are no accounts that can react with each other in both Taiwan and mainland. The remittance relies on the third party's currency with two exchange activities, which not only increase the cost of settlement, but rises the exchange risk. Furthermore, the situation also provides opportunities to illegal private banks, which devastates financial order between two areas in a large extend.

\section{B. The aspect of currency settlement mechanism}

In mainland, there are some barriers to prevent the financial integration between two areas. Firstly, bank of China and bank of communications are the only two mainland's banks with permission of services offering about exchange between RMB and TWD in their Taipei branches. On the other hand, Taiwan uses floating exchange rate regime, which mainland applies floating exchange rate regime with government intervention. Hence, it is necessary to find an efficient exchange rate mechanism to expand the effect of exchange between RMB and TWD. The other problem is that mainland can not exploit reliable channel for collection and application of TWD. Therefore, the current method is only sending new Taiwan dollar to overseas with guard and selling them. And the exchange price for TWD is only determined by the central bank, which is also known as unified price setting. This mechanism can not adjust exchange price according to the demand and supply in the market. This means that the exchange prices set by central bank is too inelastic, which offers opportunities for black market of foreign currency to engage this field.

There are also some problems should be solved in Taiwan. Firstly, there are two criteria for banks which can be authorized to provide settlement services for TWD in Taiwan, which are set by money management institute of Taiwan. The banks should set up branches in mainland and keep complete financial situation. Currently, nine banks have braches in mainland which include bank of Taiwan and Mega International Commercial bank. Furthermore, a large amount of RMB is expected to flow into Taiwan if the mechanism of currency settlement builds. It can be suggested that the methods about refluxing of RMB need to be considered. A forward step is that Taiwan residents with valid ID card and foreigners with valid passport are able to exchange between TWD and RMB. However, there is a limitation for the amount, which is no more than 20 thousand Yuan.

\section{SOLUTIONS TO BUILD FINANCIAL INTEGRATION}

\section{A. Developing supervision system for financial integration}

Currently, due to the growth trend of mixed operation in international finance industry, financial sector in mainland still apply the separate operation and separate supervision. On the other hand, Taiwan's financial industry uses mixed operation and mixed supervision. Hence, mainland and Taiwan can build a manage platform whose core is integration of financial regulation to make effective supervision for Taiwan-funded enterprises' financial activities.

And forming a Taiwan-mainland joint supervision commission is also a possible approach, which can standardize the market behavior of Taiwan-funded enterprises in mainland through exchanging relative information. Then, it will be convenient to build a effective and unified evaluation system and data base that contains all information about Taiwanfunded enterprises in mainland with the help of the commission. Before entering the mainland market, Taiwanfunded enterprises need to pass the qualification authentication conducted by Taiwan's financial supervision department, which will be based on relative standard set by mainland's financial supervision department. If their credit status can not meet the requirement in criteria of evaluation, they should reorganize according to the criteria.

\section{B. Completed legislation system between two areas}

As the openness of financial field between mainland and Taiwan, there is a dramatic change in relative field, such as financial field building, the allowance of entrance of financial institution, management about capital flow and foreign currency. Hence, the central bank should develop the legislation system between mainland and Taiwan as soon as possible. One reasonable advice is that the mainland government can set specific law for Taiwan-funded enterprises to lower the barrier of entrance for Taiwan's application about setting financial institution in mainland.

\section{Solutions about the financing limitation of Taiwan-funded enterprises}

The first solution is to establish credit guaranty institutions of Taiwan-funded enterprises. Recently, the credit guaranty system for middle and small-size enterprises is been set up gradually. The characteristic is that the majority of these credit guaranty institutions are nonprofit, and the rest of them are profitable business guaranty institutions and mutual guarantee agencies. However, this system only serves middle and smallsize enterprises rather than Taiwan-funded enterprises. Therefore, it should be strongly recommended that the government should allow Taiwan-funded credit guaranty institution, which can effectively address the financing limitation problem for Taiwan-funded enterprises.

Secondly, the cooperation platform in capital market should be built in both Taiwan and mainland. It tends to allow the enterprises in different areas to finance on both areas, which lead to effective resource distribution and complementing each other's advantage. The essential parts of the recommendation are enhancing the support for Taiwanfunded enterprises' direct financing. It will reduce the limitation about the rate of investment fund and allowance for the fund companies in each area to enter the other stock market. Then, the comparative advantages in two areas can be fully used, which will stimulate the development of rational resources allocation. 


\section{Reform experimentation building for finance integration}

Firstly, the government should enhance building of foreign exchange market in the district which contains reform experimentation. And the allowance for overseas and domestic finance institution to conduct foreign currency exchange for RMB business in free trade zone is also essential. This tends to stimulate the unification the exchange prices of RMB between mainland and Taiwan, which leads to accelerate the internationalization process of RMB.

The second advice is set exchange rate adjusting mechanism. In the test zone, the local bank can consider the Hong Kong dollar and pataca as example. Then, they can adjust the exchange price of New Taiwan dollar according to international market situation, which is account with RMB. And this adjusting behavior should not disobey the regulation of floating exchange rate range. This adjusting behavior will promote the construction of the fixed exchange rate mechanism between RMB and New dollar currency, which effectively reduces the economic loss caused by fluctuation of exchange rate.

Moreover, the financial information sharing systems is also necessary to be built. In order to realize it, we need build a financial platform between Taiwan and mainland, which can provide an excellent communication method to improve financial integration between two areas. On the other hand, it is necessary to pay more attention to the academic communication and discussion in financial field between Taiwan and mainland.

The forth advice is that it is essential to conduct training and communication systems for financial talent. The shortage of financial talent with high quality is one import problem in the process of financial integration between Taiwan and mainland. The talent exchange is able to not only facilitate their comprehension about financial market rules, supervision regulations and criteria of statistic, but also reduce the gap between the rule and regime between Taiwan and mainland.

\section{CONCLUSION}

This article demonstrates the tendency about the financial integration between mainland and Taiwan. The Inevitable tendency of financial integration has been led by the booming of economic and trade developments, the challenge caused by globalization and regionalization. The main barriers for financial integration between Taiwan and mainland are remittance barriers and currency settlement mechanism. The suggestions to overcome the barriers include supervision system developing, legislation system completed and credit guaranty institutions establishment for Taiwan-funded enterprises.

\section{REFERENCES}

11] S.G. Dai, F Yao and L.L Zhang. "Financial Integration Path Choice and Strategic Conception between Mainland China and Taiwan." Commercial Research, 2012.

[2] C.M Chao. "Will Economic Integration Between Mainland China and Taiwan Lead to a Congenial Political Culture?" Asian Survey, 2003, 43(2):280-304

[3] H Gao, "Legal issues in the economic integration agreements between China, Taiwan, HK and Macau Symposium." Cross-strait Forum on WTO Law, 2005.

[4] JJ Zhi. "Analysis on the Feasibility and Path of Financial Integration of Mainland and Taiwan." Asia-pacific Economic Review, 2010

[5] Min-Feng Lu, YJ Zhang. "Thinking of Achieving Financial Integration of Mainland and Taiwan under the New Situation.” Journal of Tianjin Institute of Financial \& Commercial Management, 2011.

[6] Luiz Fernando de Paula. Financial liberalization, exchange rate regime and economic performance in BRICs countries. London: Palgrave Macmillan UK, 2007. 